\title{
Information Technologies, students' e-skills and diversity of learning process
}

\author{
Adel Ben Youssef
}

GREDEG-CNRS, University of Nice Sophia Antipolis, Nice, France

GREDEG, 250 rue Albert Einstein, Bat 2, 06560 Valbonne, France. Tel: +33(0)4 9395 42 28. Fax: +33(0)4 936537 98. Email: adel.ben-youssef@unice.fr

Dr. Adel Ben Youssef is an Assistant Professor at the University of Nice Sophia Antipolis. His research interests and areas of expertise include: digital divides, ICT economic performances, E-learning, European integration and the Euro-Mediterranean integration process.

\section{Mounir Dahmani}

ADIS, University of Paris-Sud 11, Sceaux, France

ADIS, Faculté Jean Monnet, 54 boulevard Desgranges, 92331 Sceaux, France. Tel: +33(0)1 409117 75. Fax: +33(0)1 4091 17 75. Email: mounir.dahmani@u-psud.fr

Dr. Mounir Dahmani is an Associate Professor of economics at the University of Paris-Sud 11. His research topics covered by his $\mathrm{PhD}$ are: growth theory, competencies and ICT, e-learning, human capital and digital divides.

\section{Nessrine Omrani}

Chair Innovation and Regulation of Digital Services, Ecole Polytechnique, Paris, France

Telecom ParisTech, 37-39 rue Dareau 75014, Paris, France. Tel: +33(0)1 45818240. Email: nessrine.omrani@polytechnique.edu

Dr. Nessrine Omrani holds a position as postdoctoral fellow at Ecole Polytechnique of Paris. She has a Ph.D in economics and works with research and education within the field of the economics of intangible assets, skills and innovation in firms, and e-learning. 


\section{Information Technologies, students' e-skills and diversity of learning}

Driven by Information Technologies (IT), universities are changing in depth the nature and forms of learning processes, which are intended to prepare students to a better entry into the labour market. In this paper, we focus on the evolution of students' use of IT in such an institution characterized by organizational changes and we analyse the determinants of students' e-skills using a dataset of French university students. We show that students' involvement in the use of IT increases their e-skills. IT learning by doing and IT learning by using also increase some categories of students' e-skills. In addition, collaborative and cooperative learning are positively associated with students' advanced e-skills.

Keywords: higher education, information technologies use, e-skills, new organizational practices, collaborative learning. 


\section{Introduction}

Across the world, ICT are increasingly fundamental to a nation's socioeconomic development. It is causing major changes to our societies by transforming ways of consuming, working, producing, training and occupying leisure time. Virtually all international development organizations refer to ICT for economic and social development. Inequalities between persons are becoming more related to people's ability to use it - and how efficiently.

As regard Higher Education, use of ICT has three main consequences, for teachers, learners and educational institutions. For teachers, the range of online educational resources has grown exponentially. Teachers start, in a process of trial and error using these resources, to improve their teaching. For learners, access to these resources prompts them to investigate material in greater depth, and they can then begin self-learning and "self-apprenticeships," processes that can no longer be ignored by teachers, and thus complementary, or substitutable, to classroom interactions. Finally, all educational institutions try to structure these two consequences and to include them in their educational strategies (Hakkarainen et al. 2000). This technological revolution helps to move from the classical model of education centered on the teacher to a new model centered on the students.

Students may face several difficulties and need specific abilities to use ICT successfully (e-skills). According to the European Commission, e-competencies mean "the efficient and critical use of Information and Communication Technologies." Taking into account that the student' e-skills acquisition process may be the result of their educational, professional or personal experiences, the possibility of reverse causality is hard to exclude. However, there is only weak evidence that initial student IT skill deficiencies have a significant negative effect on the use of IT.

Technological literacy, digital literacy, technological proficiency, digital literacy self-assessment or disorientation in hypermedia has been extensively discussed in academic literature. All these terms refer to e-skills. In fact, e-skills acquisition and maintain the accumulation require a significant organizational change in higher education institutions (collaboration, innovativeness, teacher-student interaction outside the class...), diversity of learning processes (learning by doing, learning by using, and learning by failing), and an important investment by students (measured by time spent surfing on the Internet, and IT trainings).

Understanding successful use of IT in higher education and its implications is of high practical relevance. It is important for long-term strategic pedagogical planning of technology implementation in education (Jonassen et al. 2005; Nicol and MacLeod, 2005) as it affects the engagement of students in active learning and problem solving through IT (Barak et al. 2006). In recent years, this debate has intensified about the process of organizational change at the institutional level and how it is needed (Kezar, 2001). 
Empirical research is mostly devoted to industry ${ }^{1}$, few empirical works analyse the adoption of new organizational practices at universities and their impacts on the learning processes and the outputs of higher education (Ben Youssef and Ragni, 2008). In the European Union, the SEUSISS Project Final Report (2003) suggests that university students learn, develop or "pick up" their e-skills from a variety of formal and informal sources. This includes formal training sessions at school or college and informal tuition from friends, family or peers as well as self-teaching with or without the help of user manuals.

The aim of this paper is to contribute to this debate and to explore the organizational changes in French universities and its impacts on the e-skills levels of students. We find that the adoption of French Universities of new organizational changes has improved substantially the students' e-skills.

The structure of the paper is the following: Section 2 discusses the research background and the related literature. Section 3 introduces the data, the variables and the econometric methodology. Section 4 presents the results and discusses the main findings. Section 5 gives conclusions.

\section{Research background: Information Technologies, new organizational practices and e-skills}

This section is dedicated to the discussion of the research background. Firstly, we clarify the debate about e-skills and our chosen definition. Secondly, we present the different means by which organizational changes within universities may impact their eskills. Three complementary channels of organizational change are discussed: behavioural change of students induced by organizational change, strategies for diversifying the learning mechanisms and collaborative learning.

\subsection{E-skills}

Steyaert (2002) provides a classification of e-skills. He distinguishes between instrumental e-skills, i.e., the operational manipulation of technology, structural e-skills, i.e., the structure in which information is contained, and strategic e-skills, i.e., the basic

1 With respect to the debate about the productivity paradox (Triplett, 1999), performance associated with IT usage depends strongly on the adoption of New Organizational Practices (NOP) (Greenan and Mairesse, 2004; Greenan and Walkowiak, 2006). During the last decade, many firms have experienced a reorganization of their workplace. New work practices have been adopted such as job rotation, delayering, self-directed work-team, just-in-time and total quality management (Askenazy et al. 2002; Caroli and Van Reenen, 2001; Işık, and Yılmaz, 2011) find a positive impact of new work practices on productivity especially in connection with information technologies'. Askenazy and Gianella (2000), Black and Lynch (2001) and Bresnahan et al., (2002) underline the importance of introducing clusters of complementary practices. New work practices are biased against unskilled labour leading to an upskilling of firms' occupational structure. According to Arvanitis and Loukis (2009), IT, new organizational practices and human capital can contribute to firm efficiency and performance. 
readiness to pro-actively look for information, information-based decision-making and scanning of the environment for relevant information.

Concerning structure, it is not clear whether these skills are only a prospect understanding of IT tools or, in addition, include the identification of the information. van Dijk (2005) modifies Steyeart's definition. He distinguishes between operational, information, and strategic e-skills. Operational skills are the skills to operate computer and network hardware and software and can be seen as equivalent to instrumental eskills. Information skills are the skills to search, select, and process information in computer and network sources. This skill category is subdivided into formal information skills (the ability to understand and to handle the formal characteristics of a computer and a computer network such as file structures, menu structures, and hyperlinks) and substantial information skills (the ability to find, select, process, and evaluate information in specific sources of computers and networks according to specific questions and needs). And finally strategic e-skills are the capacities to use these sources as the means for specific goals and for the general goal of improving one's position in society, which corresponds to Steyeart's classification.

van Deursen and van Dijk (2010), instead of considering formal information skills and substantial information skills as subcategories of information skills, introduce formal skills for the former and information skills for the latter as two separate categories. While formal skills strongly relate to the characteristics of digital technology, information skills together with strategic skills relate to the content provided by IT tools. They distinguish between (1) operational skills as the skills to operate digital media, (2) formal skills as the skills to handle the structures of digital media, and (3) information skills as the skills to locate information in digital media and (4) strategic skills as the skills to employ the information contained in digital media towards personal and professional development.

We adopt in our paper the definition of e-skills by van Deursen and van Dijk (2010). Students' e-skills are divided into four categories starting from the basic e-skills (operational e-skills) to the more advanced ones (strategic e-skills), which are related on collaborative work. Students who only have operational e-skills tend to be the later adopters of IT. They only have skills to operate a computer. They do not use IT intensively and do not use them for collaborative work. Then, regarding formal e-skills, students in this category, in addition to operational e-skills, use some basic Internet applications. Concerning students who have the third category of e-skills (information e-skills) they use IT as tools for learning purposes in addition to the two first categories. Finally, strategic e-skills, which are the most advanced, include students who are early adopters of IT. These students use IT intensively in order to collaborate with others.

\subsection{Socio-economic impacts of e-skills}

Building e-skills has several socioeconomic impacts. Instead of listing all these effects, we discuss four illustrative impacts on human capital. Firstly, e-skills are becoming a key source of democracy, good governance and political involvement of 
citizens. If citizens have not only access to ICT but also the necessary e-skills they will be able to impacts more the policy decision making and to participate more actively in the civil society. E-skilled people are better able to access the latest (and often better) information, to blog and to take part in social media, expressing their opinions and giving feedback to politicians. Secondly, e-skills provide a powerful opportunity to improve service delivery by overcoming the geographic and financial barriers that hinder service delivery in remote areas. E-health and m-health in most developed countries are improving health sector efficiency and people's health. It is also crucial in fighting epidemics and disseminating general information on public health, and in managing health institutions more efficiently. Thirdly, e-skills have an impact on the Labor market. In fact, Nine out of 10 jobs in Europe will require e-skills. ${ }^{i}$ Ensuring plentiful e-skilled workers will both benefit from and contribute to the Internet and the knowledge economy more widely. Labor market characteristics have changed in recent years, and e-skills are becoming fundamental to workers' employability, especially among youth. Fourthly, building e-skills is vital to benefit from new business opportunities. E-skilled persons have their Capacities to create and manage e-services. They will benefit from these opportunities to make business and profits. This economic sector (e-business) is among the more dynamic one in the last decade.

\subsection{How do organizational changes within university relate to students' $e$ - skills?}

The central question of our article is to look how NOP is related to the development of student's e-skills. Nowadays universities are equipped by different IT tools (computers, Internet...). Universities let students using these tools and their personal IT tools (eg. Laptop). These new and extended usages of technology may internalize and acquire different processes in the way people do things which could be a way to develop students' new attitudes and universities new forms of learning. Starting from these considerations, our basic idea is that for effective IT use, universities may explore new forms of learning and students may develop new attitudes. These forms of learning and attitudes are not developed by the classical way of teaching within universities. The use of IT combined with the classical way of learning does not fully exploit the potential of students' IT use. Changes in the organization of classrooms and the way of teaching could improve the performance of those students who acquire more e-competencies. According to Arvanitis and Loukis (2009), the use of computer technology can lead to productivity gains through improved communication possibilities among employees.

Three main channels can be observed when university teaching is reorganized to adjust for the new possibilities of IT. First, the student-centred model of learning implies that students are more involved in all the tasks of learning. Being more autonomous and involved or being "student-centered" rather than "teacher-centered" lead students to look for information by their own. IT tools could be a way to facilitate looking for information and may lead people to intend more courses related to IT. The second channel is related to the diversity of learning mechanisms. While learning-by- 
studying is the most used form in the classical way of learning, the use of IT allows more learning mechanisms to be used, namely learning-by-doing, learning-beforedoing, learning-by-using, learning-from-competitors (other students). This diversity of the forms of learning is due to changes in the organization of courses and the organization of the whole study program. The third and last channel is related to collaborative learning. IT are also collaborative technologies and enable better students' collaboration at the universities. For this purpose, organizational changes are needed that allow for more "cooperation" and "collaboration" between students themselves and between students and teachers.

\section{(1) Students' behavioural change: autonomy, problem solving and involvement}

IT use at universities enables them to switch from a teacher-centred pedagogy to a learner-centred one (Keengwe et al. 2009; Saulnier et al. 2008). This requires an educational organization that is based on an active way of learning with different activities, which are determined by learners in small groups and where pace is determined by learners individually. By contrast, in the classical way of teaching, there is little variation in activities, they are prescribed by the teacher in a whole class instruction, and pace is determined by the program. (Barak et al. 2006) state that engagement of students in active learning and problem solving through IT is a key to pedagogically successful use of IT.

More involvement of students by using these tools and improving IT uses are a first step toward a better performance in terms of e-skills. Different learning strategies ought to be implemented in order to increase the autonomy and the involvement of the student in classroom interactions. A large part of the learning process becomes centred on interactions outside the classroom where the involvement of the student is central. These changes can be observed through the change of the students' behaviour relating to the time spent on the Internet for pedagogical purposes and of the enrolment in more courses related to IT (Ebner et al. 2010; Sivapalan and Cregan, 2005).

These organizational changes are also observed in firms. These need more autonomous workers, with the ability to take initiatives and to be fully involved in their job. Part of their job is done outside the firm's premises and the workers' capabilities developed during their higher education can be used for their jobs. To summarize, the organizational changes within universities foster e-skill acquisition and prepare prospective workers for the NOP in firms (Blass, 2005; Fernandez, 2007). These changes tend to improve their employability and increase their future wages (Knight and Yorke, 2004).

(2) Diversity of learning mechanisms instead of static learning: innovativeness, and technological absorptive capacity

"ICT has been transforming the way we communicate, the way we do business, the way we work, it is inevitable that it changes the way we learn" (Zammit, 2004). According to Zammit (2004), the learning process is changing. In the presence of IT more mechanisms of learning are available, from which students can choose. According 
to the classification by Pavitt (1985) there are at least five kind of learning processes: learning-by-using, learning-by-doing, learning-from-competitors, learning-by-failing, and learning-by-studying. Universities are seeking to diversify the mechanisms of learning through the use of IT. Many have implemented an organizational change in the organization of learning processes by developing more interactions between students and teachers and between students themselves.

The fact that students are exploring more mechanisms of learning may help them to develop their skills for more technological absorptive capacity (Hrastinski and Naghmeh, 2012). These skills are at the heart of the new organizational model of the firm today (Caroli, 2001). Firms are seeking workers who are able to learn and develop the capability to absorb new technologies and new knowledge and it appears to be important that during their higher education students develop these competencies.

\section{(3) Collaborative and cooperative learning: Modularity, team work, work by} project

IT facilitates educational collaborations between individuals and groups of people. Such collaborations may take place locally or between people in separate geographical locations. Students may collaborate with peers in other schools, teachers may collaborate with their peers, members of the local business community may serve as mentors to students, and so forth. According to (Thijs et al. 2001), there is a move from a traditional pedagogic organization to an emerging pedagogic organization (in the information society) based on an active, collaborative (working in teams within heterogeneous groups where students support each other rather than individual work in heterogeneous groups where everyone works for himself/herself), creative (productive learning rather than reproductive learning), integrative (between theory and practice and between different subjects and disciplines) and evaluative learning (towards a more diagnostic approach rather than summative and student directed rather than teacherdirected). IT and organizational change within the university are complementary as they jointly allow more cooperative and collaborative learning.

The last decade has seen major changes in French universities. Firstly, universities became more autonomous. They are in control of their own resources, setting their own strategies, and managing their own human resources. This major change implies that there is a change from a central hierarchical model of the university to a more dynamic and decentralised model where competition between universities is becoming the rule. Universities then more autonomously chose their pedagogical strategies. Secondly, French universities are trying to consider pedagogy as one of the three components for evaluating their teachers/researchers ${ }^{2}$. The two other components are publications success and involvement in the institution by taking on some responsibilities. This has led some teachers to explore new pedagogical strategies.

\footnotetext{
${ }^{2}$ Initially the evaluation was based upon publication. Higher Education Teachers were not "incited" to invest in pedagogy. Most of them have not followed any pedagogical training (Ben Youssef and Hadhri, 2009).
} 
Thirdly, several initiatives were taken in order to reverse the tendency of high student dropout rates in the initial years at university. These initiatives have tried to use IT, online tutoring, collaborative work, and work in small groups in order to improve the success and retention rate in initial years at university. These initiatives have tried to change the way courses are organized. Fourthly, several universities (especially in the fields of economics and management) have invested in the content production of elearning programs. This strategy involved teachers, staff and students. Most French universities are currently trying to offer blended learning and to use some of the resources developed online for regular students attending class.

The fact that students are trained to be cooperative and collaborative is likely to give them better prospects of successfully integrating in teams and working by projects. These abilities are also important requirements in the professional world and, thus, critical success factors in the labour market. Improving these kinds of skills in higher education can thus be seen as important investments for the labour market. As alluded to above, these NOP are widely used within the firms nowadays. Several contributions have shown that the complementarities between the adoption of organizational change and adoption of IT lead to better productivity of firms’ performances. By acquiring these competencies students are better skilled and have greater probability of having a job (Hakkarainen et al. 2000).

\section{Data and variables}

\subsection{Data collection}

The data were collected by a survey conducted in France in 2010. The survey investigates the adoption and use of IT by students. We used the survey approach, instrumented via a face-to-face questionnaire data-gathering technique.

The questionnaire includes four parts: the first concerns the characteristics of the student, the second explores the motivation of the student for study, the third seeks to assess the facilitating conditions, while the fourth seeks to account the diversity of IT uses which students use.

A pilot study with a group of 20 students was undertaken in order to ensure the questions were adapted appropriately to the research context. The purpose was to find out potential problems and misunderstandings of instruction and question items. After the pilot test, some small adjustments were made. Finally, a total of 1522 students took part in the survey. In order to accomplish the research objectives and the econometric analysis of the data, it was necessary to exclude respondents that reported inconsistent responses and respondents who did not answer all the questions. After these adjustments the sample consists of 1464 observations.

\subsection{Sample characteristics}

The final sample contains 1464 students in the field of economics and management from three French universities. Of the surveyed students, $69.3 \%$ belong to the University of Paris-Sud 11, 21.2\% to the University of Nice Sophia-Antipolis and 
9.5\% to the University of Paris 10 . Around $40 \%$ of respondents were carrying out their first year of undergraduate degree studies, $36.1 \%$ their second year of undergraduate degree and $23.8 \%$ their third and final year of the undergraduate degree. 33\% of the sample carried out professional activities in parallel with their studies. In our sample, $52.3 \%$ of all students are male and $47.7 \%$ female. Respondents' ages are divided into various age groups. The age mean of our sample is 21. The average age of female students is 20 while it is 21 for male. The descriptive statistics are summarized in Table 1 .

Table 1. Sample description

\begin{tabular}{|c|c|c|c|c|}
\hline Variable $(\mathrm{N}=1464)$ & Mean & Std. Dev. & Min & Max \\
\hline Gender (Male) & 0.477 & & 0 & 1 \\
\hline Age & 1.878 & 0.844 & 1 & 4 \\
\hline 17 to 19 & 0.393 & & 0 & 1 \\
\hline 20 to 21 & 0.367 & & 0 & 1 \\
\hline 22 to 23 & 0.208 & & 0 & 1 \\
\hline 24 and more & 0.031 & & 0 & 1 \\
\hline University & 1.402 & 0.656 & 1 & 3 \\
\hline University of Paris-Sud 11 & 0.693 & & 0 & 1 \\
\hline University of Nice-Sophia Antipolis & 0.212 & & 0 & 1 \\
\hline University of Paris 10 & 0.095 & & 0 & 1 \\
\hline Level of education & 1.838 & 0.783 & 1 & 3 \\
\hline First year of undergraduate degree & 0.400 & & 0 & 1 \\
\hline Second year of undergraduate degree & 0.361 & & 0 & 1 \\
\hline Third and final year of undergraduate degree & 0.238 & & 0 & 1 \\
\hline Having a job while studying & 0.330 & & 0 & 1 \\
\hline Having a computer at home & 0.889 & & 0 & 1 \\
\hline Having a laptop & 0.805 & & 0 & 1 \\
\hline Internet connection at home & 0.962 & & 0 & 1 \\
\hline Provision IT training by the university & 0.680 & & 0 & 1 \\
\hline Time spent on the Internet for educational purposes & 2.171 & 0.940 & 1 & 5 \\
\hline Less than one hour per week & 0.201 & & 0 & 1 \\
\hline 1 to 5 hours & 0.559 & & 0 & 1 \\
\hline 6 to 9 hours & 0.148 & & 0 & 1 \\
\hline 10 to 14 hours & 0.053 & & 0 & 1 \\
\hline 15 hours and more & 0.039 & & 0 & 1 \\
\hline
\end{tabular}

\subsection{Definitions of the variables}

\subsubsection{Dependent variable: Students' e-skills}

The participants in our survey were asked to rate their level of skills and the frequency with which they use nineteen IT applications. These IT variables are specified through five-point Likert scale responses, ranging from value " 1 ” for students who have neither adopted, nor tested these technologies to value " 5 " for the earliest adopters and those who use them intensively. 
To characterize the different modes of IT usages and skills, a Principal Component Analysis (PCA) was conducted with the nineteen variables. The PCA (see Table 2) uncovers four factors that summarize the different modes of IT usages and skills (accounting for $53.33 \%$ of the total variance).

Table 2. Results of the Principal Component Analysis for the different modes of IT usages and skills

\begin{tabular}{|c|c|c|c|c|}
\hline \multirow[t]{2}{*}{ Items } & \multicolumn{4}{|c|}{ Factors } \\
\hline & F1 & F2 & F3 & F4 \\
\hline Proficiency in presentation software & 0.821 & & & \\
\hline Proficiency in word processing software & 0.802 & & & \\
\hline Proficiency in spreadsheet software & 0.786 & & & \\
\hline Proficiency in discipline-specific software & 0.559 & & & \\
\hline Proficiency in device installation & 0.528 & & & \\
\hline Proficiency in social networks applications & & 0.769 & & \\
\hline Proficiency in forum and chat applications & & 0.731 & & \\
\hline Proficiency in messaging software & & 0.656 & & \\
\hline Proficiency in search engine & & 0.528 & & \\
\hline Encyclopaedias use as support of courses & & & 0.735 & \\
\hline Databases use as support of course & & & 0.706 & \\
\hline Forums use as support of course & & & 0.563 & \\
\hline Team work using IT & & & & 0.806 \\
\hline Internet use as a tool for setting goals & & & & 0.777 \\
\hline Technology use to facilitate working with colleagues & & & & 0.736 \\
\hline Task work using Internet & & & & 0.717 \\
\hline Parallel work on multiple projects using IT & & & & 0.635 \\
\hline Internet use for research projects & & & & 0.591 \\
\hline Internet use to facilitate information flow & & & & 0.498 \\
\hline
\end{tabular}

F1: The generic use of computer

F2: The generic use of Internet

F3: The use of IT for pedagogic purposes

F4: The use of IT for collaborative work purposes

A non-hierarchical cluster analysis (ESKILLS) based on k-means methodology is then carried out based on the scores revealed by the PCA. The version with four clusters of e-skills is adopted and can be interpreted as following:

Profile 1: Operational e-skills (ESKILLS_1). This group includes 25.96\% of students (380 students) who are the later adopters of the IT and do not use them intensively. They typically have text processing skills and have used some aspects of presentation and spreadsheets software. Generally, students from Profile 1 have not used specialized software or collaborative applications. They especially have the basic skills to operate the computer.

Profile 2: Formal e-skills (ESKILLS_2). This group includes $32.51 \%$ of students (476 students) who in addition to possessing the operational skills listed in Profile 1, declared to use Internet applications like search engine, network application and messaging software. Students from Profile 2 tend to have some information skills. 
Profile 3: Information e-skills (ESKILLS_3). This group (356 students; 24.32\%) is represented by students who are not proficient in IT but have sophisticated learning mechanisms are willing to learn new IT tools to reconstruct their learning practices. This group is also strong on operational and formal skills.

Profile 4: Strategic e-skills (ESKILLS_4). Students belonging to this group (252 students; 17.21\%) are earlier adopters and use IT intensively. They are characterized by high e-skills. In addition, the use of collaborative applications is widespread in this cluster indicating that especially students who have expertise in and access to these IT tools are using IT to support collaborative learning.

The four dummy variables ESKILLS_1, ESKILLS_2, ESKILLS_3 and ESKILLS_4 used in the econometric analysis below result from this procedure. They represent the four identified modes of IT usages.

\subsubsection{Independent variables}

Students' characteristics: Gender, students' age, level of education, home university and having job while studying can be expected to influence student's e-skills levels.

IT access: IT access is measured by different items, which relate to both IT equipment such as the possession of a laptop or a computer at home, having domestic Internet connection and IT help and support such as the availability of disciplinespecific software, the availability of help and support and IT training provided by the university.

Students' involvement: Students' involvement reflects the students' effort in order to use IT efficiently. This variable is measured by two items, which are first, students' IT training, coded as a " 1 " if the respondent answered with a "yes (=1)", otherwise a "no (=0)". Second, students were also asked about the use of Internet for pedagogical purposes. They ranked the extent of their usage on a scale of five points (15) specifically, less than one hour per week (1), from 1 to 5 hours (2), from 6 to 9 hours (3), from 10 to 14 hours (4), and more than 15 hours (5).

Learning mechanisms: Two sets of variables were used to measure students' learning mechanisms: IT learning by doing and IT learning by using. In our survey we assume that a student accumulates IT skills by doing if he/she tries out new applications, if he/she is an early tester of new computer applications or if he/she participates in applications development. Furthermore, two variables tap the IT learning by using dimension. Two items assess mobile devices use: flexible versus fix scheduled work and use of mobile tools. The students were asked if working at any time during the day is more efficient than working at fixed time and whether they use mobile tools in order to prepare their homework.

Collaborative and cooperative learning: In order to measure students' collaborative and cooperative learning, we use seven items. IT use is seen as collaborative and cooperative learning tools when the student believes that Internet use enhances collaboration with other students, when he/she states that Internet use improves the work presentation and organization. This variable is also measured by the 
student's belief that Internet is useful to provide business creation ideas and innovative ideas, and that IT is important for learning due to the fact that these tools give them the opportunity to contact the teacher or the tutor by e-mail. In addition, it measures the ability to communicate and to discuss a course issue online and the belief that Internet use enables them to obtain a deeper understanding of the content developed in class. Respondents were asked to indicate the extent of their agreement with each item on a five-point scale, ranging from 1-strongly disagree to 5-strongly agree.

\subsection{Econometric model}

The objective of this study is to identify the determinants of students' e-skills. We assume that the probability that a student is in one of the four different categories of e-skills depends on his/her characteristics, involvement to the use of IT, the level of IT use, and the use of IT tools for collaborative and cooperative purpose. Under this assumption of a discrete choice, the appropriate model is a multinomial logit ${ }^{3}$, shown in equation below ${ }^{4}$. This model determines if the relevant factors identified in the literature review (presented above) are related to the probability of students to be in one of the four different e-skills categories. Let ESKILLS denote the $i^{\text {th }}$ student's category of eskills variable, which can then be observed as:

$$
\text { ESKILLS }=\left\{\begin{array}{l}
=1 \text { if student } i \text { has operational e-skills } \\
=2 \text { if student } i \text { has formal e-skills } \\
=3 \text { if student } i \text { has information e-skills } \\
=4 \text { if student } i \text { has strategic e-skills }
\end{array}\right.
$$

\section{Empirical results}

The results are presented in Tables 3 and 4 in terms of significance, marginal effects (ME) and the odds-ratios (reported under the $\operatorname{Exp}(\beta)$ ). The overall fit of the model is satisfactory and confirms that student's characteristics, IT access, the student's involvement, learning mechanisms, and collaborative and cooperative learning are crucial when explaining the e-skills acquisition patterns. The usual specification tests give satisfactory results (Wald and LR tests).

Table 3. Results from the multinomial logit model

\begin{tabular}{|l|l|l|l|}
\hline $\begin{array}{l}\text { Dependent variables } \\
\text { Structural e-skills }\end{array}$ & Formal e-skills & $\begin{array}{c}\text { Information e- } \\
\text { skills }\end{array}$ & Strategic e-skills \\
\hline \multicolumn{4}{|l|}{} \\
\hline Independent variables & \multicolumn{4}{|l|}{} \\
\hline Student characteristics & $0.03(0.167)$ & $-0.04(0.193)$ & $0.56^{* *}(0.249)$ \\
\hline Gender &
\end{tabular}

\footnotetext{
${ }^{3}$ Please note that we also tested our adoption equation through ordered logit and ordered probit models. The results achieved were very similar, which confirms the robustness of the equation. Nevertheless, the multinomial logit model was preferred insofar as it is difficult to interpret the ESKILLS_3 and ESKILLS_4 classes as ordered in terms of categories of e-skills.

${ }^{4}$ See e.g. Maddala (1993) or Franses and Paap (2001).
} 


\begin{tabular}{|c|c|c|c|}
\hline University of Paris-Sud 11 & Ref. & Ref. & Ref. \\
\hline University of Nice-Sophia Antipolis & $0.90 * * *(0.237)$ & $-0.08(0.289)$ & $1.22 * * *(0.337)$ \\
\hline University of Paris 10 & $0.28(0.299)$ & $-0.30(0.350)$ & $0.07(0.439)$ \\
\hline \multicolumn{4}{|l|}{ Level of education } \\
\hline First year of undergraduate degree & Ref. & Ref. & Ref. \\
\hline Second year of undergraduate degree & $0.11(0.217)$ & $-0.07(0.251)$ & $0.11(0.318)$ \\
\hline $\begin{array}{l}\text { Third and final year of undergraduate } \\
\text { degree }\end{array}$ & $0.10(0.253)$ & $0.32(0.285)$ & $0.64 *(0.373)$ \\
\hline \multicolumn{4}{|l|}{ Age } \\
\hline 17 to 19 & Ref. & Ref. & Ref. \\
\hline 20 to 21 & $0.05(0.214)$ & $0.18(0.247)$ & $0.31(0.309)$ \\
\hline 22 to 23 & $-0.22(0.258)$ & $-0.42(0.297)$ & $-0.48(0.388)$ \\
\hline 24 and older & $-1.30 * * *(0.474)$ & $-1.49 * * *(0.531)$ & $-2.10 * * *(0.780)$ \\
\hline Having a job while studying & $0.24(0.178)$ & $0.40 * *(0.201)$ & $0.61 * * *(0.249)$ \\
\hline \multicolumn{4}{|l|}{ IT access } \\
\hline Having a computer at home & $-0.13(0.242)$ & $0.12(0.293)$ & $1.30 * * *(0.485)$ \\
\hline Having a laptop & $0.17(0.188)$ & $0.39 *(0.233)$ & $0.58 *(0.320)$ \\
\hline Internet connection at home & $0.42(0.386)$ & $0.10(0.497)$ & $-1.27 * *(0.649)$ \\
\hline Availability of discipline-specific software & $0.04(0.070)$ & $0.26 * *(0.085)$ & $0.27 * * *(0.113)$ \\
\hline Availability of help and support & $0.01(0.069)$ & $0.11(0.079)$ & $0.23 * *(0.105)$ \\
\hline The university provides IT training & $0.52 * * *(0.169)$ & $0.30(0.199)$ & $0.47 *(0.267)$ \\
\hline \multicolumn{4}{|l|}{ Students' involvement } \\
\hline Student IT use training & $0.18(0.168)$ & $0.50^{* * *}(0.190)$ & $0.43 *(0.240)$ \\
\hline \multicolumn{4}{|c|}{ Hours spent per week surfing for pedagogical purposes } \\
\hline Less than one hour & Ref. & Ref. & Ref. \\
\hline 1 to 5 hours & $0.05(0.191)$ & $0.41 *(0.247)$ & $-0.30(0.323)$ \\
\hline 6 to 9 hours & $0.42(0.293)$ & $1.01^{* * *}(0.341)$ & $0.06(0.426)$ \\
\hline 10 to 14 hours & $0.34(0.489)$ & $1.15^{* *}(0.520)$ & $1.55^{* * *}(0.580)$ \\
\hline 15 hours and more & $-0.33(0.685)$ & $0.62(0.696)$ & $1.76^{* * *}(0.716)$ \\
\hline \multicolumn{4}{|l|}{ Learning mechanisms } \\
\hline \multicolumn{4}{|l|}{ Learning by doing } \\
\hline To test new applications & $0.18(0.111)$ & $0.25 * *(0.130)$ & $0.63 * * *(0.158)$ \\
\hline Primary tester of new computer applications & $0.43^{* * *}(0.107)$ & $0.40^{* * *}(0.123)$ & $0.38 * * *(0.146)$ \\
\hline Applications development & $0.25 * * *(0.085)$ & $0.37 * * *(0.093)$ & $0.44 * * *(0.106)$ \\
\hline \multicolumn{4}{|l|}{ Learning by using } \\
\hline Flexible versus fixed schedule & $0.10(0.067)$ & $0.18^{* *}(0.077)$ & $0.26^{* * *}(0.099)$ \\
\hline Use of mobile tools & $0.08(0.063)$ & $0.21^{* * *}(0.071)$ & $0.41 * * *(0.091)$ \\
\hline \multicolumn{4}{|l|}{ Collaborative and cooperative learning } \\
\hline $\begin{array}{l}\text { Internet use enhances collaboration with } \\
\text { other students }\end{array}$ & $0.25 * * *(0.077)$ & $0.35^{* * *}(0.092)$ & $0.52^{* * *}(0.122)$ \\
\hline $\begin{array}{l}\text { Internet use improves the work presentation } \\
\text { and organization }\end{array}$ & $-0.04(0.081)$ & $0.16^{*}(0.096)$ & $0.52^{* * *}(0.132)$ \\
\hline Internet provides business creation ideas & $0.14(0.089)$ & $0.12(0.099)$ & $0.55^{* * *}(0.122)$ \\
\hline Internet provides innovative ideas & $0.09(0.090)$ & $0.22 * *(0.102)$ & $0.25 * *(0.135)$ \\
\hline $\begin{array}{l}\text { Having the opportunity to contact the } \\
\text { teacher / tutor by e-mail }\end{array}$ & $0.28 * * *(0.078)$ & $0.39 * * *(0.096)$ & $0.35^{* * *}(0.132)$ \\
\hline $\begin{array}{l}\text { Being able to communicate and discuss a } \\
\text { course issues online }\end{array}$ & $-0.09(0.076)$ & $0.22^{* * *}(0.088)$ & $0.35^{* * *}(0.117)$ \\
\hline $\begin{array}{l}\text { Internet use enables student to deepen the } \\
\text { content developed in class }\end{array}$ & $0.17 * *(0.077)$ & $0.32 * * *(0.092)$ & $0.44^{* * *}(0.124)$ \\
\hline
\end{tabular}




\begin{tabular}{|l|l|}
\hline \multicolumn{2}{|l|}{} \\
\hline Pseudo $\mathrm{R}^{2}$ & 27.76 \\
\hline Log likelihood & -1440.6086 \\
\hline LR(96) & $1106.97^{* * *}$ \\
\hline
\end{tabular}

Table 4. Marginal effects of the multinomial logit model

\begin{tabular}{|c|c|c|c|c|c|c|}
\hline \multirow{2}{*}{$\begin{array}{l}\text { Dependent variables } \\
\text { Structural e-skills }\end{array}$} & \multicolumn{2}{|c|}{ Formal e-skills } & \multicolumn{2}{|c|}{ Information e-skills } & \multicolumn{2}{|c|}{ Strategic e-skills } \\
\hline & $\operatorname{Exp}(\beta)$ & $\begin{array}{l}\text { Marginal } \\
\text { Effects }\end{array}$ & $\operatorname{Exp}(\beta)$ & $\begin{array}{l}\text { Marginal } \\
\text { Effects }\end{array}$ & $\operatorname{Exp}(\beta)$ & $\begin{array}{l}\text { Marginal } \\
\text { Effects }\end{array}$ \\
\hline \multicolumn{7}{|l|}{ Independent variables } \\
\hline \multicolumn{7}{|l|}{ Student characteristics } \\
\hline Gender & 1.03 & 0.005 & 0.96 & -0.024 & $1.74^{* *}$ & $0.035^{* * *}$ \\
\hline \multicolumn{7}{|l|}{ University } \\
\hline University of Paris-Sud 11 & Ref. & - & Ref. & - & Ref. & - \\
\hline $\begin{array}{l}\text { University of Nice-Sophia } \\
\text { Antipolis }\end{array}$ & $2.45 * * *$ & $0.179 * * *$ & 0.92 & -0.156 & $3.38 * * *$ & $0.057 * * *$ \\
\hline University of Paris 10 & 1.32 & 0.107 & 0.74 & -0.096 & 1.07 & 0.001 \\
\hline \multicolumn{7}{|l|}{ Level of education } \\
\hline $\begin{array}{l}\text { First year of undergraduate } \\
\text { degree }\end{array}$ & Ref. & - & Ref. & - & Ref. & - \\
\hline $\begin{array}{l}\text { Second year of undergraduate } \\
\text { degree }\end{array}$ & 1.12 & 0.034 & 0.93 & -0.032 & 1.12 & 0.005 \\
\hline $\begin{array}{l}\text { Third and final year of } \\
\text { undergraduate degree }\end{array}$ & 1.11 & 0.040 & 1.38 & 0.039 & $1.90^{*}$ & 0.055 \\
\hline \multicolumn{7}{|l|}{ Age } \\
\hline 17 to 19 years & Ref. & - & Ref. & - & Ref. & - \\
\hline 20 to 21 years & 1.06 & -0.021 & 1.20 & 0.024 & 1.36 & 0.015 \\
\hline 22 to 23 years & 0.81 & 0.015 & 0.66 & -0.048 & 0.62 & -0.015 \\
\hline 24 years and older & $0.27 * * *$ & -0.120 & $0.23 * * *$ & $-0.120^{*}$ & $0.12^{* * *}$ & $\begin{array}{l}- \\
0.047^{* * *}\end{array}$ \\
\hline Having a job during studies & 1.27 & 0.015 & $1.49 * *$ & 0.038 & $1.84 * * *$ & $0.067 * *$ \\
\hline \multicolumn{7}{|l|}{ IT access } \\
\hline Having a computer at home & 0.88 & -0.076 & 1.13 & 0.025 & $3.69 * * *$ & $0.056 * * *$ \\
\hline Having a laptop & 1.19 & 0.026 & $1.48 *$ & 0.047 & $1.78^{*}$ & 0.077 \\
\hline Internet connection at home & 1.52 & 0.150 & 1.11 & 0.024 & $0.28 * *$ & $-0.171 *$ \\
\hline $\begin{array}{l}\text { Availability of discipline- } \\
\text { specific software }\end{array}$ & 1.04 & -0.033 & $1.30 * * *$ & $0.044 * * *$ & $1.31^{* * *}$ & $0.010^{*}$ \\
\hline Availability of help and support & 1.00 & -0.021 & 1.11 & 0.017 & $1.26^{* *}$ & $0.012^{* *}$ \\
\hline $\begin{array}{l}\text { The university provides IT } \\
\text { training }\end{array}$ & $1.68^{* * *}$ & $0.074^{* *}$ & 1.35 & 0.015 & $1.61^{*}$ & 0.052 \\
\hline \multicolumn{7}{|l|}{ Students' involvement } \\
\hline Training in the use of IT & 1.19 & 0.039 & $1.65 * * *$ & $0.073 * * *$ & $1.53^{*}$ & 0.051 \\
\hline \multicolumn{7}{|c|}{ Hours spent per week surfing for pedagogical purposes } \\
\hline Less than one hour & Ref. & - & Ref. & - & Ref. & - \\
\hline 1 to 5 hours & 1.06 & 0.032 & $1.10 *$ & $0.084^{* *}$ & 0.74 & -0.030 \\
\hline 6 to 9 hours & 1.53 & 0.054 & $2.73 * * *$ & $0.163 * * *$ & 1.06 & 0.028 \\
\hline 10 to 14 hours & 1.41 & 0.146 & $3.16^{* *}$ & $0.157^{* *}$ & $4.71 * * *$ & $0.083^{*}$ \\
\hline 15 hours and more & 0.72 & -0.229 & 1.86 & 0.087 & $5.82 * * *$ & $0.196 * *$ \\
\hline \multicolumn{7}{|l|}{ Learning mechanisms } \\
\hline Learning by doing & & & & & & \\
\hline
\end{tabular}




\begin{tabular}{|l|l|l|l|l|l|l|l|}
\hline Test of new applications & 1.19 & -0.009 & $1.28^{* *}$ & 0.015 & $1.89^{* * *}$ & $0.030^{* * *}$ \\
\hline $\begin{array}{l}\text { Primary tester of new computer } \\
\text { applications }\end{array}$ & $1.53^{* * *}$ & $0.041^{* *}$ & $1.49^{* * *}$ & 0.037 & $1.47^{* * *}$ & 0.033 \\
\hline Applications development & $1.29^{* * *}$ & 0.017 & $1.44^{* * *}$ & $0.034^{* * *}$ & $1.56^{* * *}$ & $0.013^{* * *}$ \\
\hline Learning by using & \multicolumn{5}{|l|}{} \\
\hline Flexible versus fixed schedule & 1.11 & 0.007 & $1.19^{* *}$ & 0.018 & $1.30^{* * *}$ & $0.010^{* *}$ \\
\hline Use of mobile tools & 1.08 & 0.022 & $1.24^{* * *}$ & $0.026^{* *}$ & $1.50^{* * *}$ & $0.019^{* * *}$ \\
\hline Collaborative and cooperative learning \\
\hline $\begin{array}{l}\text { Internet use enhances } \\
\text { collaboration with other students }\end{array}$ & $1.29^{* * *}$ & 0.022 & $1.42^{* * *}$ & $0.029^{* *}$ & $1.69^{* * *}$ & $0.018^{* * *}$ \\
\hline $\begin{array}{l}\text { Internet use improves work } \\
\text { presentation and organization }\end{array}$ & 0.96 & -0.048 & $1.18^{*}$ & $0.029^{*}$ & $1.67^{* * *}$ & $0.031^{* * *}$ \\
\hline $\begin{array}{l}\text { Internet provides business } \\
\text { creation ideas }\end{array}$ & 1.15 & 0.002 & 1.12 & 0.006 & $1.73^{* * *}$ & $0.028^{* * *}$ \\
\hline $\begin{array}{l}\text { Internet provides innovative } \\
\text { ideas }\end{array}$ & 1.10 & 0.015 & $1.25^{* *}$ & $0.029^{*}$ & $1.28^{* * *}$ & 0.038 \\
\hline $\begin{array}{l}\text { Having the opportunity to } \\
\text { contact the teacher / tutor by e- } \\
\text { mail }\end{array}$ & $1.32^{* * *}$ & 0.025 & $1.47^{* * *}$ & $0.037^{* * *}$ & $1.42^{* * *}$ & 0.066 \\
\hline $\begin{array}{l}\text { Being able to communicate and } \\
\text { discuss a course issues online }\end{array}$ & 0.91 & -0.064 & $1.25^{* * *}$ & $0.052^{* * *}$ & $1.42^{* * *}$ & $0.021^{* * *}$ \\
\hline $\begin{array}{l}\text { Internet use enables student to } \\
\text { deepen the content developed in } \\
\text { class }\end{array}$ & $1.19^{* *}$ & 0.014 & $1.37^{* * *}$ & $0.034^{* *}$ & $1.56^{* * *}$ & $0.056^{* * *}$ \\
\hline
\end{tabular}

Note: The notation $* * *, * *$, and $*$ denotes significance at the $1 \%, 5 \%$ and $10 \%$.

The estimation reveals that the student's gender has a statistically significant effect on the probability of having strategic e-skills. The estimated odds-ratio for male is 1.74 for strategic e-skills category suggesting that the change increases the odds of having strategic e-skills instead of having only operational e-skills by $74 \%$ in the considered category.

Regarding students' ages, older students are less likely to have all types of eskills compared to relatively young ones (17-19 age group). This means that the older the students the more they are able to have operational skills.

The probability of being in the "strategic e-skills" class is significantly influenced by the presence of IT facilities. The availability of equipment tends to improve the probability of having information and strategic e-skills and mainly strategic ones. Furthermore, help and support have a positive and significant impact on having strategic e-skills compared to operational e-skills. An increase of one unit improves the odds by 1.26 , which means an increase of $26 \%$ of strategic e-skills. Nevertheless, regarding "providing IT training by the university"; an increase by one unit enhances significantly the odds of having formal e-skills compared to the reference category by $68 \%$.

\section{Student's involvement}

Regarding students' involvement, with respect to "IT use training by students", an increase by one unit enhances significantly the odds of having information e-skills by 1.65 compared to operational e-skills implying an increase of $65 \%$ of the odds. 
Pertaining to time spent surfing on the Internet for learning purposes, the more the student spent time surfing, the higher the probability of having strategic e-skills compared to operational e-skills increases.

Our estimates indicate how an operational change in the organization of higher education improves the acquisition of e-skills. Students' involvement by giving them the incentives to spend more time on Internet for pedagogical uses and for following courses related to IT increase their probability to acquire e-skills. Moreover involvement impacts the nature of these e-skills. It allows students to acquire high level of e-skills (strategic and informational e-skills).

\section{Diversity of learning mechanisms}

The diversity of learning mechanisms, especially IT learning by doing and learning by using appears to have a significant positive effect on all types of e-skills. For instance, one unit's increase of "application development" or "mobile use for studies" increases the odds of having information and strategic e-skills by $24-44 \%$ and 50-56\% respectively rather than operational e-skills.

Again, these findings suggest the need for operational changes in universities to diversify the forms of learning mechanisms. This diversity of learning mechanisms improves the acquisition of all the forms of e-skills. At the same time we have seen their large impact on strategic skills.

\section{Collaboration and cooperation}

With regard to collaborative and cooperative learning, items in general reflect a positive and significant impact on the probability of having information and strategic eskills compared to operational ones. In fact, with respect to students' views that Internet use enhances collaboration with other students. In other words, the fact that Internet use enhances collaboration with others increases significantly the probability of having information e-skills and strategic e-skills by respectively $42 \%$ and $69 \%$. Furthermore, an increase in the belief that IT gives students the opportunity to contact the teacher by e-mail by one unit multiplies the odds of having formal e-skills, information e-skills and strategic e-skills by respectively 1.32, 1.47 and 1.42 .

These findings suggest that organizational changes are correlated with the process of e-skills acquisition. Encouraging collaborative learning and improving cooperation between students through the use of IT inside and outside the classroom allow them to acquire valuable e-skills (in particular, strategic skills).

\section{Summary of our three key findings}

Firstly, students' involvement increases the accumulation of their e-skills. IT training enhances students' information e-skills. This could be explained by combining basic e-skills with learning through training based on IT use leading to more sophisticated e-skills (the strategic ones). Spending more hours surfing on the Internet for learning purpose also improves students' e-skills. Students who spend more time surfing on the Internet have more sophisticated e-skills. 
Secondly, the diversity of learning processes enhances the accumulation of students' e-skills. The outcomes with regard to the relationships between learning processes and students' e-skills show the importance of IT learning by doing and IT learning by using to enhance e-skills. While IT learning by doing enhances all types of e-skills, IT learning by using enhances information e-skills and mainly strategic e-skills. This result shows the importance of using IT tools to improve more sophisticated eskills. Thus, strategies based on facilitating IT learning by using are needed. These strategies could be reflected by letting students using IT tools for learning purposes and letting them work in teams in order to use frequently distant tools (e.g. e-mail, videoconference...).

Thirdly, collaborative and cooperative learning facilitates the accumulation of students' e-skills. Since technological change and organizational change are considered to be complementary, effective IT use at universities, as well as at firms, requires collaborative and cooperative competencies as both academic and professional environments undergo changes. When students understand that IT tools facilitate communications between them and with teachers (which tends to improve the students' knowledge and then their performance) they tend to use IT more often. This in turn enhances their more sophisticated e-skills.

\section{Concluding remarks and Recommendations}

The link between organizational change and the use of IT allows students to acquire e-skills more efficiently. Internal organizational changes in universities are similar to those observed within modern firms (team work, project work, total quality, collaborative work, distance work, modular work, autonomy...).

The results of our multinomial logit model for French data confirm the hypothesis of the existence of a correlation between organizational changes and e-skills acquired by students. In fact, our study contributes to a growing body of literature discussing students' e-skills accumulation. IT integration in higher education has been steadily gaining interest over the past decade. However, challenges remain in implementing the right organizational changes in order to support the use of IT and to enhance students' e-skills acquisition. Higher education institutions also may be blatantly or inadvertently blocking IT development due to incoherent plans for inclusion and misunderstandings of the needed organizational changes. Our article has analysed how changes in the organization of learning can impact different types of e-skills acquisition by students and the nature of these skills. Further research is needed in order to extend the findings to other socio-cultural contexts.

\section{Recommendations}

Starting from the fact that most Higher Education Institutions have access to a wide range of tools, applications and digital content is available for students and teachers, and require the skills mentioned above. Beyond that, states should consider the following. Ensuring connectivity at school: The first step is to ensure that connectivity and equipment in schools are progressing, enabling more frequent classroom interactions 
and generating e-skills among learners. Public policies, the market and technological changes are resolving the access problem. African countries are showing great interest in ICT for education and are bridging the equipment gap with huge public investment and initiatives. The market, through competition between firms and technology providers, has ensured a steep fall in ICT prices, enabling schools and learners to be better equipped. Finally, technology is evolving, permitting applications and less costly equipment (such as cloud computing).

Using a learner-centered, not teacher-centered, approach: Building e-skills requires this shift. Investing in teacher training and their new roles and, more challengingly, moving from the Socratic, face-to-face, 2,500-year old model of education are the first steps in building e-skills. They require enhanced teacher confidence, as their beliefs about technology are a major obstacle for ICT classroom use. "If teachers are not confident in their ability or competence to handle computers, this may hamper their willingness to introduce technology in their classrooms. Using tools and applications to change the nature of learning: Several studies show that effectiveness of ICT in education needs simultaneous use of these elements for students to change their way of learning. It also leads to a shift in use of ICT and innovative exploration of ICT.

Structuring the informal process of learning: Students are autonomously exploring new technologies and are accessing digital education contents outside the classroom. Teachers need to take advantage of these new forms of learning by strengthening eskills of students so that they absorb learning informally. These new roles for teachers must be included in their curricula, and they must have special training. 


\section{References}

Arvanitis, S., Loukis, E. N. (2009). Information and communication technologies, human capital, workplace organization and labour productivity: A comparative study based on firm-level data for Greece and Switzerland. Information Economics and Policy, 21(1), 43-61.

Askenazy, P., Caroli, E., Marcus, V. (2002). New organizational practices and working conditions: Evidence from France in the 1990’s. Recherches Économiques de Louvain / Louvain Economic Review, 68(1-2), 91-110.

Askenazy, P., Gianella, C. (2000). Le paradoxe de productivité : les changements organisationnels, facteur complémentaire à l'informatisation. Economie et Statistique, 339(1), 219-241.

Barak, M., Lipson, A., Lerman, S. (2006). Wireless laptops as means for promoting active learning in large lecture halls. Journal of Research on Technology in Education, 38(3), 245-263.

Ben Youssef, A., Hadhri, W. (2009). Les dynamiques d'usage des technologies de l'information et de la communication par les enseignants universitaires : le cas de la France. Réseaux, 27(155/2009), 25-54.

Black, S. E., Lynch, L. M. (2001). How to compete: The impact of workplace practices and information technology on productivity. The Review of Economics and Statistics, 83(3), 434-445.

Blass, E., 2005. The rise and rise of the corporate university. Journal of European Industrial Training 29 (1), 58-74.

Bresnahan, T. F., Brynjolfsson, E., Hitt, L. M. (2002). Information technology, workplace organization, and the demand for skilled labor: Firm-level evidence. The Quarterly Journal of Economics, 117(1), 339-376.

Caroli, E. (2001). Organizational change, new technologies and the skill bias: What do we know? In: Petit, P., Soete, L. (Eds.), Technology and the Future of European Employment. Edward Elgar, pp. 259-292.

Caroli, E., Van Reenen, J. (2001). Skill-biased organizational change? Evidence from a panel of British and French establishments. The Quarterly Journal of Economics, 116(4), 1449-1492.

Ebner, M., Lienhardt, C., Rohs, M., Meyer, I. (2010). Microblogs in higher education a chance to facilitate informal and process-oriented learning? Computers and Education, 55(1), 92-100.

Fernandez, J. A. (2007). The future of corporate universities in Europe. Global Focus, 2(2), 40-43.

Franses, P. H., Paap, R. (2001). Quantitative models in marketing research, 1st Edition. Cambridge University Press, Cambridge.

Greenan, N., Mairesse, J. (2004). A Firm Level Investigation of the Complementarity between Information and Communication Technologies and New Organizational Practices. In: 79th Annual conference of the Western Economic Association International. June 29-July 3, 2004. Vancouver, Canada. 
Greenan, N., Walkowiak, E. (2006). Information technology, work organization and social interactions. Economie et Statistique, 387, 35-63.

Hakkarainen, K., Ilomaki, L., Lipponen, L., Muukkonen, H., Rahikainen, M. (2000). Students' skills and practices of using ICT: Results of a national assessment in Finland. Computers and Education, 34(2), 103-117.

Hrastinski, S., Naghmeh M. (2012). How are campus students using social media to support their studies? An explorative interview study. Education and Information Technologies, 17(4), 451-464.

Işık, C., Yılmaz, S. (2011). E-learning in life long education: a computational approach to determining listening comprehension ability. Education and Information Technologies, 16(1), 71-88.

Jonassen, D., Lee, C. B., Yang, C.-C., Laffey, J. (2005). The collaboration principle in multimedia learning. In: The Cambridge Handbook of Multimedia Learning. Richard Mayer, pp. 247-270.

Keengwe, J., Onchwari, G., Onchwari, J. (2009). Technology and student learning: Toward a learner-centered teaching model. AACE Journal, 17(1), 11-22.

Kezar, A. J. (2001). Understanding and facilitating organizational change in the 21st century: recent research and conceptualizations, 1st Edition. Vol. 28 of J-B ASHEERIC Report Series (AEHE) Series. Jossey-Bass, Washington, DC.

Knight, P., Yorke, M. (2004). Learning, Curriculum and Employability in Higher Education. RoutledgeFalmer, London.

Maddala, G. S. (1993). Limited-Dependent and Qualitative Variables in Econometrics. Cambridge University Press, Cambridge.

Nicol, D. J., MacLeod, I. A., (2005). Using a shared workspace and wireless laptops to improve collaborative project learning in an engineering design class. Computers and Education 44(4), 459-475.

Pavitt, K. (1985). Patent statistics as indicators of innovative activities: Possibilities and problems. Scientometrics, 7(1,2), 77-99.

Saulnier, B. M., Landry, J. P., Longenecker, H. E., Wagner, T. A. (2008). From teaching to learning: Learner-centered teaching and assessment in information systems education. Journal of Information Systems, 19(2), 169-175.

SEUSISS Project Final Report (2003). Survey of European universities skills in ICT of students and staff. Tech. rep.

Sharma, S. (1995). Applied Multivariate Techniques. John Wiley and Sons, Inc, New York.

Sivapalan, S., Cregan, P. (2005). Value of online resources for learning by distance education. CAL-laborate 14, 23-27.

Steyaert, J. (2002). Inequality and the digital divide: myths and realities. In: McNutt, S. H. J. (Ed.), Advocacy, activism and the internet. Lyceum Press. Chicago, pp. 199-211.

Su, K.-D. (2008). An integrated science course designed with information communication technologies to enhance university students' learning performance. Computers and Education, 51(3), 1365-1374. 
Thijs, A., Almekinders, R., Blijleven, P., Pelgrum, W., Voogt, J. (2001). Learning through the web: a literature study on the potential uses of the web for student learning. Tech. rep., University of Twente, Faculty of Educational Science and Technology, Department of Curriculum, Enschede.

Triplett, J. E., (1999). The Solow productivity paradox: what do computers do to productivity? Canadian Journal of Economics, 32(2), 309-334.

Tuparovaa, D., Tuparova, G. (2010). Automated real-live performance-based assessment of ICT skills. Procedia - Social and Behavioral Sciences 2 (2), 4747-4751.

van Deursen, A. J. A. M., van Dijk, J. A. (2010). Measuring internet skills. International Journal of Human-Computer Interaction, 26(10), 891-916.

van Dijk, J. A. (2005). The Deepening Divide Inequality in the Information Society. Sage Publications, Thousand Oaks, California.

van Dijk, J. A. (2006). Digital divide research, achievements and shortcomings. Poetics, 34(4-5), 221-235.

Zammit, L. (2004). Literacy in ICT skills. Tech. rep. The Lisbon Objectives and the Maltese Education Provision.

i European Commission 2011. 